\title{
CALCULUS FORMATION IN THE SEMINAL VESICLES
}

\author{
Major K. D. ELLIS, M.B., F.R.C.S., F.R.C.S. (Edin.), R.A.M.C. \\ British Military Hospital, Iserlohn
}

SUMMARY: The case of a thirty-three year old man presenting with terminal haematuria, worse after intercourse, and due to multiple calculi in the left seminal vesicle is discussed. A review of the literature since 1913 shows that many cases are found incidentally and others present with a wide variety of symptoms.

\section{Introduction}

Calculus formation in the seminal vesicles is rare. A case is reported with recurrent, painless, terminal haematuria as the presenting disorder and in which unilateral nonspecific epididymitis developed, before the underlying pathology was elucidated.

\section{Case Report}

The patient was a married soldier aged 33 years. He had been seen elsewhere in November 1966 with a six weeks history of terminal haematuria, worse after intercourse. There was no history of trauma, infection or service in the tropics. Rectal examination at that time was normal. His urine was sterile but showed occasional white and red blood cells. No acid-fast bacilli were demonstrated on smear or culture, and no schistosomes were seen. Full blood count and erythrocyte sedimentation rate were normal. Cystoscopy on two occasions in December 1966 showed mild trigonitis only. Intravenous pyelography on 16 December 1966 appeared normal but in retrospect there was evidence of reflux into the left seminal vesicle. On the 19 th of December he had a recurrence of frank haematuria. On cystoscopy the bladder was normal but urethroscopy showed bleeding from the posterior urethra, which was controlled with an indwelling catheter.

When seen on 18 September 1967 the patient gave a three months history of swelling of the left testis with associated ache in the left groin. There was no history of trauma and he admitted of no further urinary symptoms. On examination there was a hard, smooth, one centimetre diameter non-tender swelling at the lower pole of the left epididymis. The left seminal vesicle felt thickened and nodular per rectum. Urinalysis, blood urea and full blood count were normal. No acid-fast bacilli were isolated from the urine and the Heaf test was negative. Intravenous pyelography showed normal kidneys and ureters but demonstrated a sharply marginated, irregularly calcified shadow to the left of the midline at bladder level.

On 20 November 1967 left epididymectomy was performed. The macroscopic appearance suggested tuberculosis but histologically there was generalised round cell infiltration, oedema, congestion and an occasional giant cell. No tubercles or acid-fast bacilli were seen. On the 28 th of November a micturating cystogram showed the rounded calcified shadow, previously noted, to be posterior to the bladder in the region of the left seminal vesicle. A narrow column of dye extended upwards from the lesion.

Repeat cystoscopy on 24 January 1968 showed no abnormality but was followed by slight haematuria. On the 31 st January there was a recurrence of frank terminal haematuria with no other symptoms. This settled rapidly and on the 5th of February a repeat micturating cystogram showed reflux into the seminal vesicular lesion, which 
varied in size, and also reflux into the proximal vas deferens (Fig. 1). On the 10th of February, under general anaesthetic, cystoscopy showed a normal bladder and a left

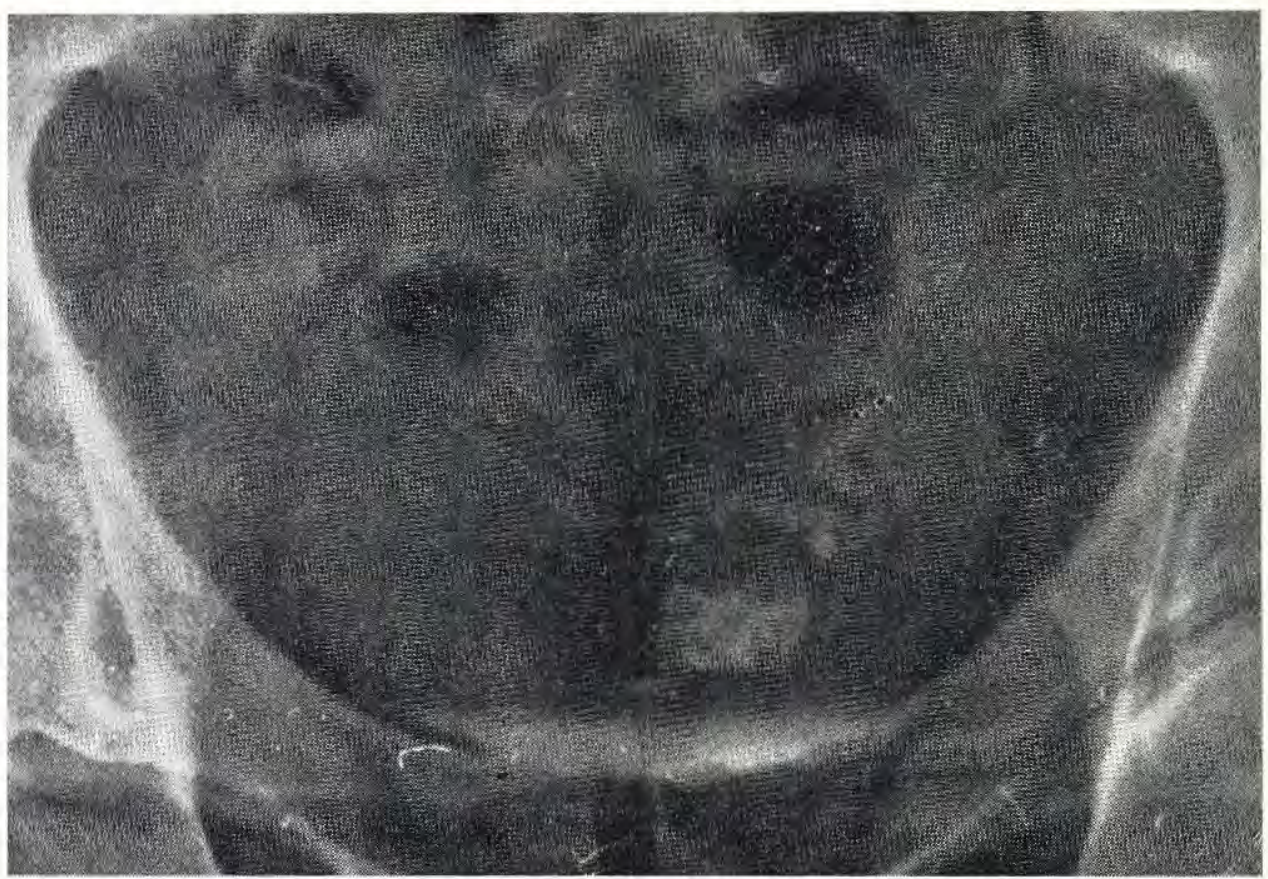

Fig. 1. Micturating cystogram showing reflux into left seminal vescicle and left vas deferens.

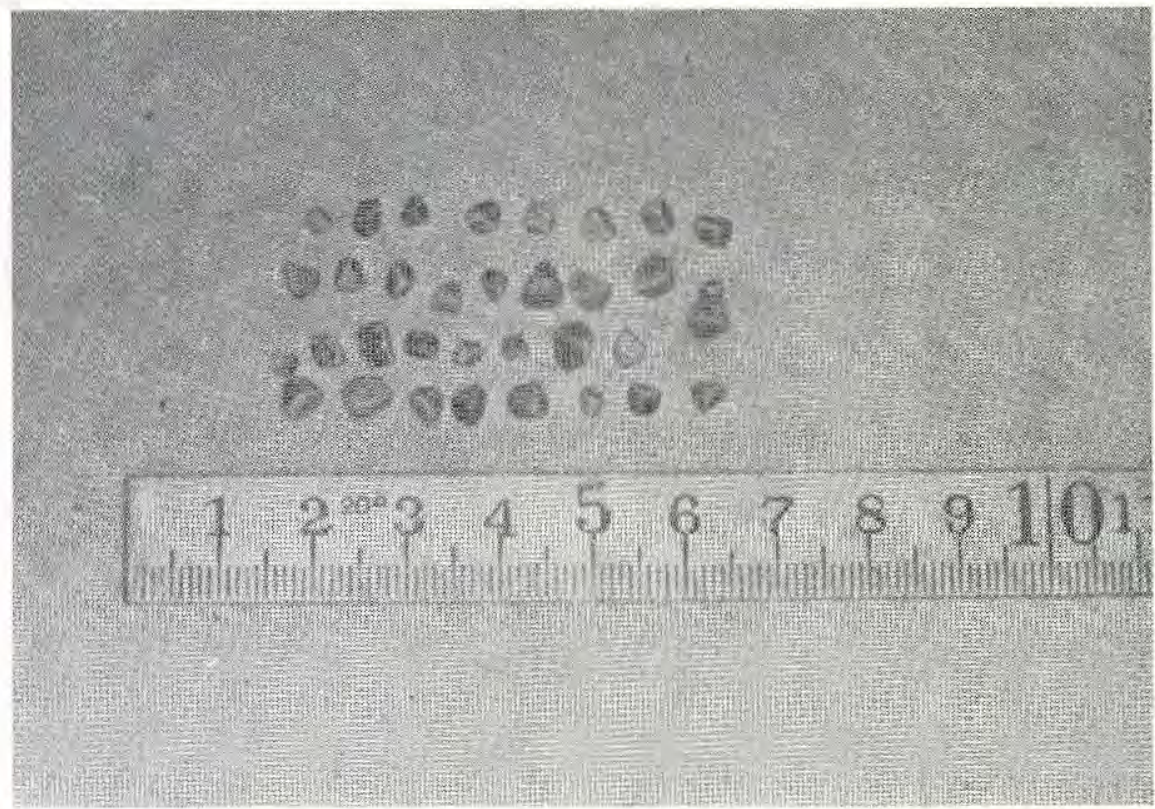

Fig. 2. Seminal vesicular calculi. 
retrograde pyelogram appeared normal. Through a midline hypogastric incision the bladder was opened and the left seminal vesicle approached by splitting the trigone. It was enlarged, thick walled and contained numerous facetted calculi. The vesicle and a segment of the vas deferens were excised and the bladder was closed in layers with perurethral drainage. The postoperative course was uneventful and the patient remained well thereafter.

Examination of the excised seminal vesicle showed infiltration of all layers of the tubules with chronic inflammatory cells and some follicle-like collections of round cells. Some of the tubules contained concretions. About thirty small facetted calculi, of fairly uniform size (3-4mm faces), consisted largely of ammonium phosphate (Fig. 2).

\section{Discussion}

Text books of urology make brief reference to calculi of the seminal vesicles. Isolated reports have appeared at intervals in the literature and are summarised in Table $I$.

Table I

Summary of reports of calculi of the seminal vescicles

\begin{tabular}{|c|c|c|c|c|c|c|}
\hline Reference & Age & Presentation & $\begin{array}{l}\text { No. of } \\
\text { stones }\end{array}$ & $\begin{array}{l}\text { Radio- } \\
\text { opaque }\end{array}$ & $\begin{array}{l}\text { Side } \\
\text { affected }\end{array}$ & Treatment/How found \\
\hline $\begin{array}{l}\text { James and } \\
\text { Schumann (1913) }\end{array}$ & 33 & "Renal colic" & Four & - & Right & Found at post mortem \\
\hline Corner (1915) & - & Haemospermia & One & - & - & $\begin{array}{l}\text { Removed during enuc- } \\
\text { leation of prostate }\end{array}$ \\
\hline $\begin{array}{l}\text { Beyer }(1917) 10 \\
\text { refs } 1861-1912\end{array}$ & 63 & - & Numerous & Yes & Bilateral & Found at post mortem \\
\hline Heckel (1938) & 47 & Found on X-ray & Numerous & Yes & Bilateral & - \\
\hline Camerer (1939) & 46 & 一 & Several & - & Right & Chance finding \\
\hline $\begin{array}{l}\text { Lowsley and } \\
\text { Kirwin (1944) }\end{array}$ & - & - & Numerous & - & Bilateral & Found at post mortem \\
\hline Marusiak (1952) & - & - & Several & - & Right & $\begin{array}{l}\text { Chance finding in } \\
\text { patient with prostatic } \\
\text { hypertrophy and right } \\
\text { renal calculi }\end{array}$ \\
\hline Cornwell (1954) & $\begin{array}{l}34 \\
20\end{array}$ & $\begin{array}{l}\text { Suprapubic pain } \\
\text { Urethal discharge } \\
\text { Terminal haematuri } \\
\text { "Ureteric pain" }\end{array}$ & $\begin{array}{l}\text { One } \\
\text { One }\end{array}$ & Yes & $\begin{array}{l}\text { Left } \\
\text { Right }\end{array}$ & $\begin{array}{l}\text { Removed via perineum } \\
\text { Removed via perineum }\end{array}$ \\
\hline Le Manna (1961) & 60 & 一 & One & - & Left & $\begin{array}{l}\text { Found at post mortem. } \\
\text { Also chronic calcifying } \\
\text { prostatitis, haemorr- } \\
\text { hagic ulcerative cystitis } \\
\text { and left sided } \\
\text { pyelonephritis }\end{array}$ \\
\hline Varis (1965) & - & - & - & - & - & $\begin{array}{l}\text { Treated by } \\
\text { vesiculolithotomy }\end{array}$ \\
\hline Durban (1965) & 35 & $\begin{array}{l}\text { Dysuria and left } \\
\text { iliac fossa pain. } \\
\text { Palpable per } \\
\text { rectum }\end{array}$ & One & Yes & Left & Vesiculolithotomy \\
\hline
\end{tabular}


The causes of calculus formation in the seminal vesicles are listed as stagnation from poor drainage, infection and simply precipitation round spermatozoa (Herbut; 1952). Corner (1915) emphasized primary prostatic pathology and stated " those who suffer from an enlarged prostate commonly have some secondary affection of the vesiculae. The adenomatous tumours, which causes the enlargement of the prostrate obstruct the expulsion of sperm. The vesiculae become dilated, pouched and chronically inflamed-chronic infective vesiculitis; their contained fluid becoming at times inspissated to form calculi. The symptoms which might arise therefrom are dwarfed and obscured by those of the enlarged prostate." Beyer (1917) also thought inspissation and calcification of seminal fluid secondary to obstruction important, this usually occurring in elderly patients in whom there had been cessation of sexual function. Oberndorfer (1931) agreed and stated that the course of development could be followed in diverticula of the vesicles. He notes that "calculi have mostly been found in seriously ill patients, and on the whole they have only been discovered accidentally at autopsy". Lowsley and Kirwin (1944) give obstruction of the ejaculatory ducts, with stagnation of the seminal fluid and metabolic disturbances as aetological factors. Cornwell (1954) postulated that "Inflammation or congestion has prompted bleeding with retention of a small clot which became calcified instead of being evacuated or absorbed".

Most writers agree that obstruction is important; subsequent inspissation and deposition of various salts occurs. In our patient reflux into the vesicle and vas was easily demonstrated; stagnation was therefore unlikely, unless one postulates some form of intermittent obstruction at the level of the ejaculatory ducts. Campbell (1957) states that the nuclei are epithelial cells. Beyer (1917) found that "spermatozoa have been repeatedly demonstrated in the nucleus". The chemical content varies and includes " lime salts", hydrochlorates and sulphates of potassium and calcium, albumen and mucus. Camerer (1939) found 92 per cent protein with calcium and sodium in the ash. The calcium content varies considerably as is shown by the various radiological appearances. In addition to spermatozoa seminal fluid contains protein, inorganic phosphates, acid phosphates, ammonia, lactose, fructose, organic acids and a variety of enzymes (Campbell, 1963). Prostatic secretion contains calcium in larger amounts than blood plasma. In the patient described the calculi were very firm, brownish-yellow in colour and multifacetted. On drying they fragmented and were seen to consist of an inorganic shell, (Fig. 3). The nucleus was not analysed but may have consisted of spermatozoa or epithelial cells or debris. The salts precipitated were presumably derived from seminal fluid and also prostatic fluid and urine, since reflux was demonstrated, and also because of the high ammonia content. The reflux was the cause of the non-specific epididymitis, and was also an important factor in calculus formation. Graves and Engel (1950) showed that reflux of sterile urine along the vas can cause epididymitis. At no time was the urine of this patient shown to be infected. Campbell (1963) however states that nonspecific epididymitis is usually a complication of infected urine, though the infection may not be proven. It is not uncommon following urethral instrumentation, and may occur in the course of seminal vesiculitis, prostatitis, cystitis or urethral stricture. Straining may be a factor in forcing organisms along the lumen of the vas.

Symptoms if present may be overshadowed by those of other local or distant pathology. Severe colic, simulating renal colic, perineal pain or discomfort at the time of intercourse, priapism, haemospermia, frequency, dysuria and haematuria have all been noted. Rectal palpation and radiological demonstration of the calculi confirm the diagnosis. 


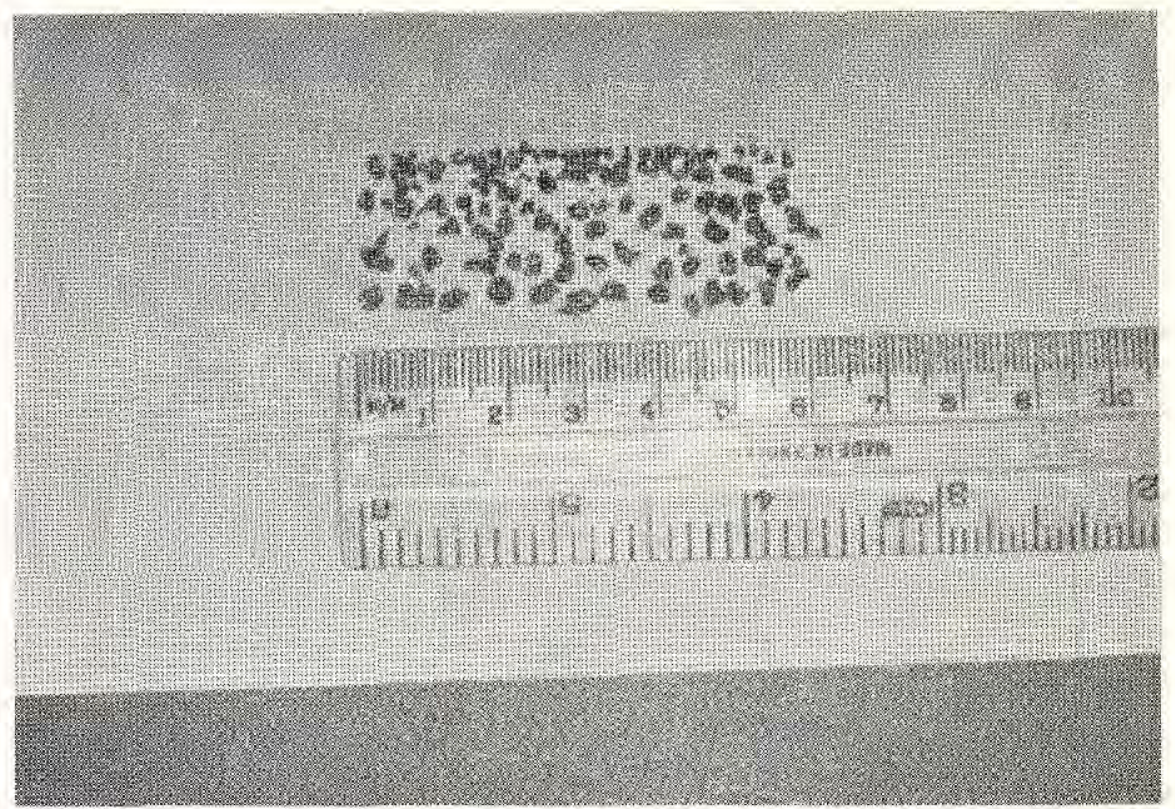

Fig. 3. Seminal vesicular calculi after desication.

If the symptoms warrant interference the treatment of choice is vesiculectomy or vesiculotomy and removal of the calculi.

\section{REFERENCES}

Beyer, T. E. (1917). Trans. Chic. path.Soc, X, 149.

Camerer, J. (1939). Frankfurt. Z. Path. 53, 313.

Campbell, M. F. (1957). Principles of Urology. Saunders. London.

CAMPBeli, M. F. (1963). Urology. Vol. 1. Saunders. London.

Corver, E. M. (1915). Med. Press 99, 134.

CORNWELL, P. M. (1954). J. Urol.(Baltimore). 72, 243.

Durban, V. J. (1965), J. Philipp. med. Ass. 41, 290.

GRAves, R. S. and ENGE,, W. T. (1950). J. Urol. (Baltimore). 64, 601.

HECKEL, N. J. (1938). Amer, J. Roentgenol. 39, 377.

HeRnU1, E. (1952). Urological Pathology. Kimpion. London.

James, C. S, and Schumann, J. W. (1913). Surg. Gynec. Obstet. 16, 302.

La Manna, S. (1961). Riv. Anat. pat. 20, 136.

LowSLey, O. S. and KJRwin, R. J. (1944). Clinical Urology, Williams and Wilkins. Baltimore.

Marusiak, J. (1952). Acta. radiol. bahemosl. 5, 180.

Orerndorter, S. (1931). Handbk Spee, Paih. Anat. and Histol. 3, 566.

VARIS, A. (1965), Nord Med. 73, 479. 